\section{Biosynthesis of a New Ascorbic Acid Analog by D-Gluconolactone Dehydrogenase of Penicillium cyaneo-fulvum}

\author{
Shigeo MUrakawa and Takeshi TakaHashi \\ Department of Agricultural Chemistry, \\ Tokyo Noko University, \\ Fuchu, Tokyo 183, Japan
}

Received June 29, 1977

In the preceding paper, ${ }^{1)}$ we have reported on the purification and some properties of $\mathrm{D}$ glucono- $\gamma$-lactone dehydrogenase, D-erythorbic acid (D-EA) producing enzyme of Penicillium cyaneo-fulvum. It was difficult to determine whether the true substrate of this enzyme was D-glucono- $\gamma$-lactone or $\delta$-lactone, because the both lactones equilibrated to each other depending on the reaction $\mathrm{pH}$. It was considered, however, that D-EA was produced from $\gamma$-lactone by the enzyme. This communication demonstrates the formation of a new ascorbic acid analog from $\delta$-lactone by the enzyme and its non-enzymatic transformation to D-EA.

$P$. cyaneo-fulvum IFO 8140 was grown with shaking at $30^{\circ} \mathrm{C}$ in a synthetic medium. ${ }^{13}$ After 6-days incubation, the mycelia were harvested, washed and autolyzed. The enzyme was purified from the lyzate as described previously. ${ }^{1}$ The reactions were carried out at $30^{\circ} \mathrm{C}$ in different$\mathrm{pH}$ buffers with $2 \mathrm{~mm}$ EDTA, and were started by the addition of the powdered lactones. The products were measured by hydrazine method, using D-EA as a standard.

Figure 1 shows the effect of $\mathrm{pH}$ on the enzyme reaction with $\gamma$ - and $\delta$-lactones. At all $\mathrm{pH}$ range tested, the enzyme reacted faster with $\delta$-lactone than with $\gamma$-lactone. The reaction products were analyzed by paper chromatography, according to the method of Miki and Sahashit' (Fig. 2). At pH 5.6, main product from $\gamma$ - and $\delta$-lactones was identified as D-EA, on the other hand, at $\mathrm{pH} 4.0$, an unknown

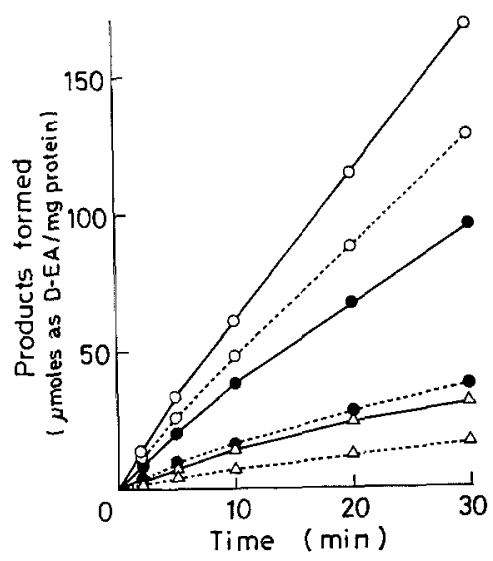

Fig. 1. Effect of $\mathrm{pH}$ on the Enzyme Reactions with $\gamma$ - and $\delta$-Lactones.

Reactions were carried out at $30^{\circ} \mathrm{C}$ in McIlvaine's citric acid $(0.1 \mathrm{M})$-phosphate $(0.2 \mathrm{M})$ buffer, $\mathrm{pH}(\mathrm{O})$ 5.6, (•) 4.0 and $(\triangle) 3.0$, with $2 \mathrm{mM}$ EDTA, $15 \mu \mathrm{g} / \mathrm{ml}$ of enzyme protein and $50 \mathrm{~mm}$ of $(-) \delta$-lactone or (-----) $\gamma$-lactone.

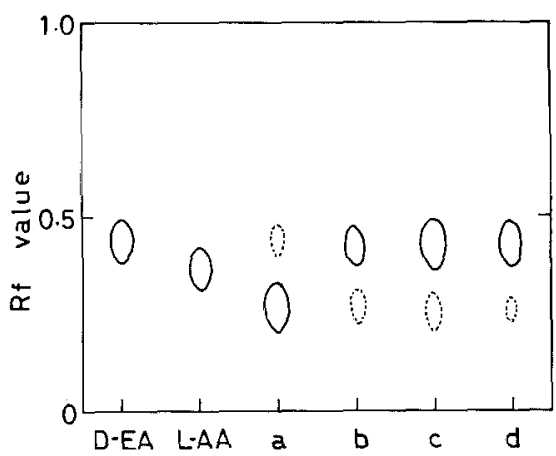

FIG. 2. Paper Chromatogram of the Reaction Products.

After 1-hr incubation, reaction mixtures were spotted on the paper, developed for $1 \mathrm{hr}$ in $\mathrm{CH}_{3} \mathrm{COC}_{2} \mathrm{H}_{5}$ saturated with water, and colored by indophenol reduction. a, pH 4.0, $\delta-; \mathrm{b}, \mathrm{pH} 4.0, \gamma-; \mathrm{c}, \mathrm{pH} 5.6, \delta-$; d, pH 5.6, $\gamma$-lactone; L-AA, L-ascorbic acid.

2,6-dichlorophenolindophenol (DCIP)-reducing spot was detected from $\delta$-lactone. Hydrolysis and equilibrium reactions of these lactones proceed rapidly at $\mathrm{pH} 5.6$ or higher, and very gradually at $\mathrm{pH} 4.0 \sim 3.0 .^{2,3}$ So the reaction products might be derived mainly from the substrates themselves added at the lower $\mathrm{pH}$, while, from the equilibrium complexes at the higher $\mathrm{pH}$. 


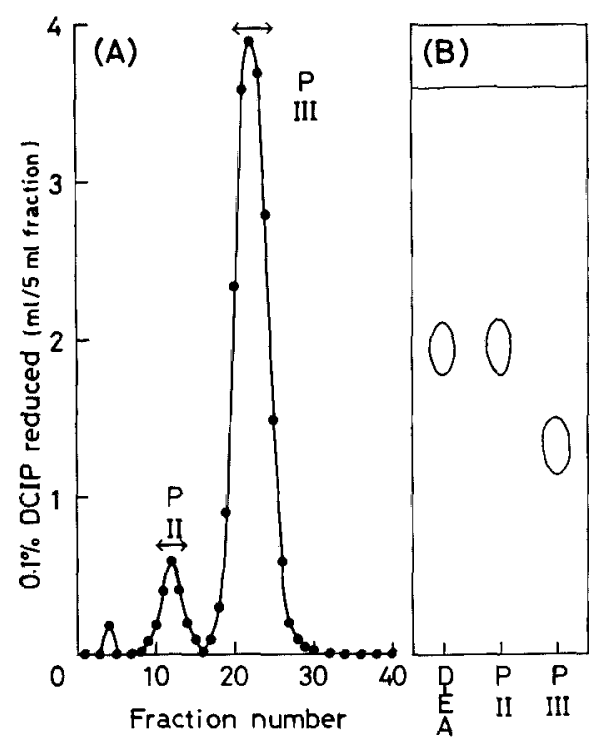

Frg. 3. Purification of the Analog by Silica-gel Column Chromatography.

Reaction mixture at $\mathrm{pH} 4.0$ and $30^{\circ} \mathrm{C}$ for $1 \mathrm{hr}$ with $\hat{\delta}$-lactone was separated by 1 st silica-gel column, and the analog fractions were collected and applied to 2nd column $(1 \times 17 \mathrm{~cm})(\mathrm{A})$. Fractions after elution with water-saturated $50 \% t$-butanol in chloroform were analyzed by paper chromatography (B).

The unknown product was purified by 2 nd silica-gel column to give a single spot on paper chromatogram (Fig. 3). Using this preparation, some properties of the analog were investigated. It was oxidized by air, DCIP or $\mathrm{Br}$, and re-reduced by $\mathrm{H}_{2} \mathrm{~S}$. Oxidized analog reacted with 2,4-dinitrophenylhydra- zine to give an osazone derivative as same as that of D-EA. After several-hr incubation in buffer at $\mathrm{pH} 5.6$ or higher, most of the analog changed rapidly to D-EA, and at the lower $\mathrm{pH}$, it was more stable and changed gradually to D-EA.

From these results, we estimate that the enzyme reacts with $\gamma$-lactone to form D-EA having $\gamma$-ring, and with $\delta$-lactone to form unknown analog having $\delta$-lactone ring. Then, the analog may change non-enzymatically to $\mathrm{D}-\mathrm{EA}$, depending on $\mathrm{pH}$ of the reaction mixture. This analog was also produced by resting cells of $P$. cyaneo-fulvum incubated with D-glucose. This may be a bypass of the D-EA-biosynthetic pathway from glucose by Penicillium. " The details of chemical identification of the analog will be needed to support the above speculations.

In conculusion, the enzyme, D-glucono- $\gamma$ lactone dehydrogenase should be corrected to D-gluconolactone dehydrogenase.

\section{REFERENCES}

1) T. Takahashi, H. Yamashita, E. Kato and S. Murakawa, Agric. Biol. Chem., 40, 121 (1976).

2) T. Takahashi and M. Mitsumoto, Nature, 199, 765 (1963).

3) K. Shimahara and T. Takahashi, Biochim. Biophys. Acta, 201, 410 (1970).

4) T. Miki and Y. Sahashi, Vitamins, 25, 171 (1962).

5) T. Takahashi and M. Mitsumoto, Biochim. Biophys. Acta, 51, 410 (1961). 